\title{
A CSILLAGÁSZAT GAIA KORA
}

\section{THE GAIA AGE OF ASTRONOMY}

\author{
Szabados László \\ az MTA doktora, kutató professor emeritus \\ Csillagászati és Földtudományi Kutatóközpont Konkoly Thege Miklós Csillagászati Intézet, Budapest \\ szabados@konkoly.hu
}

\begin{abstract}
ÖSSZEFOGLALÁS
Az Európai Űrügynökség Gaia-űrszondájának sikeres múködése valódi korszakváltást hoz a csillagászatban. A Gaia jelenleg is végzi asztrometriai méréseit, ám az eddig nyilvánosságra hozott adatok alapján is számos helyen át kell írni a csillagászati tankönyveket, kézikönyveket. A tanulmány az űrasztrometria bemutatása után a Gaia projektet ismerteti, és néhány példával érzékelteti, hogy milyen tudományos áttörésekhez vezettek a Gaia eddigi mérési adatai.
\end{abstract}

\section{ABSTRACT}

The success of the Gaia space probe of the European Space Agency results in a new revolution in astronomy. Gaia is still performing astrometric measurements but based on the available data several chapters of astronomy textbooks and handbooks have to be revised. Following the introduction into space astrometry, this paper describes the Gaia project and shows several examples of breakthroughs in astronomy owing to astrometric measurements by Gaia.

Kulcsszavak: asztrometria, csillagászat, Gaia, parallaxis, távolság

Keywords: astrometry, astronomy, Gaia, parallax, distance

\section{ASZTROMETRIA A FÖLDRŐL}

Az asztrometria az égitestek helyét és látszó égi mozgását vizsgálja. A 19. század közepéig, az asztrofizika kialakulásáig az asztrometriai mérések jelentették magát a csillagászatot. Később, már a 20. században a kozmológia hasított ki magának újabb szeletet a csillagászat „tortájából”. Azonban a csillagászat 
bármely részterületével foglalkozó szakemberek sem boldogulhatnak az asztrometria nélkül, amire az asztrometria másik elnevezése is utal: fundamentális csillagászat.

Egy égitest térbeli helyzetét hat adat írja le: megfelelően választott koordináta-rendszerben mért három koordinátaérték, továbbá a három koordinátairány menti mozgást jellemző adat. Az égi világban azonban már a pillanatnyi koordináták mérése sem egyszerü. És itt nem arról van szó, hogy a Föld tengely körüli forgása miatt minden csillag, galaxis és a naprendszerbeli kisebb-nagyobb égitestek látszó helye folyton változik az égen. A koordináta-rendszer alkalmas megválasztásával az éggömbön elfoglalt hely, azaz két koordinátaérték egyszerüen megadható, csak a mérési pontosság szüntelen növelésére van szükség, mivel a jelenleg müködő óriástávcsövekkel észlelhetö leghalványabb csillagok felületi sürüsége elképesztően nagy is lehet az égen. A fö gond a „térbeliségre” jellemzö harmadik koordinátával van, hiszen azt is meg kell mérni, hogy a csillag (galaxis, kozmikus köd, kisbolygó stb.) milyen távol van tőlünk az adott látóirány mentén. Amíg a távolság nem ismert, a szóban forgó objektum fizikai tulajdonságai (mérete, tömege, sugárzási teljesítménye) is bizonytalanok.

A távolságot a csillagászatban a geodéziában használt háromszögelés jól bevált módszerével határozzák meg. Egy szakasz (,,alapvonal”) két végén elhelyezett müszerrel megmérik, hogy a kiszemelt tereptárgy milyen irányban látszik, majd a szakasz hossza és a teodolittal mért két szög ismeretében egyszerü trigonometriai számolással adódik a tereptárgy távolsága a mérőeszköztől. Ugyanígy érzékeli az emberi szem is a távolságot. A szem esetében az alapszakasz végpontjai a két pupilla közepe. Azt a jelenséget, hogy felváltva bal és jobb szemmel nézve a közelebbi tárgyak elmozdulni látszanak a háttérben levőkhöz képest, parallaxisnak nevezik. Minél távolabbi objektumot vizsgálunk, annál kisebb a parallaktikus elmozdulás. Földi tárgyak esetében jól mérhető ez a szög. Az égitestek világában viszont a Földön megszokottnál sok-sok nagyságrenddel nagyobb távolságok jellemzőek, a parallaxisból eredő szögkülönbség pedig ugyanennyi nagyságrenddel csökken. A csillagászatban tehát extrém pontos mérésekre van szükség, még akkor is, ha az alapszakasz hossza ugyancsak nagyságrendekkel meghaladja a geodéziai méréseknél megszokott értéket. A csillagászok számára a Föld Nap körüli keringése ugyanis kb. 300 millió kilométer hosszú alapszakaszt biztosít (ennyi a földpálya átmérője). E szakasz két végpontjába fél év különbséggel kerül a Föld, ekkor lehet elvégezni a megfelelö szögmérést. (Persze máskor is lehet mérni, csak figyelembe kell venni a Föld pillanatnyi helyzetét.)

A kozmikus távolságmérés nehézségét fokozza az a tény, hogy földi távcsövekkel nem lehet abszolút szögeket mérni a szükséges pontossággal, csupán a távcső látómezejében látszó égitestek pozíciója közötti szögkülönbséget. Parallaktikus eredetủ elmozdulása viszont a látómezőbe kerülő minden objektumnak van, a 
távolabbiaknak kisebb, a közelebbieknek nagyobb szögérték. De ez a „nagyobb” is egészen csekély számérték: a Naphoz legközelebbi csillag, a Proxima Centauri parallaxisa kisebb 1 ívmásodpercnél. Így érthető, hogy a csillagászati parallaxismérések csak az 1830-as években vezettek először sikerre. Az egészen kis szögkülönbségekből meghatározott távolság bizonytalansága ugyanis egészen nagy lehet a szögmérés hibája miatt.

A parallaxismérés módszerének fő előnye az, hogy geometriai (trigonometriai) alapon nyugszik, és teljesen független a vizsgált égitestek tulajdonságaitól. Földi távcsővel végzett mérések esetén a pontosság legfeljebb 0,01 ívmásodperc, így a parallaxismérés csupán 200-300 fényév távolságig használható. Összehasonlításul: a Tejútrendszer átmérője kb. százezer fényév. Földfelszíni távcsövekkel végzett parallaxismérésből ezért csak néhány ezer csillag távolságát sikerült megállapítani, a kapott távolságértékeket pedig többnyire nagy hiba terheli.

Mivel a távolság ismerete a csillagászatban alapvető, a csillagászok kénytelenek voltak kidolgozni más távolságmeghatározási módszereket is. E módszerek közös vonása az, hogy a vizsgált objektumok valamilyen fizikai jellemzőjén, tehát bizonyos előfeltevésen alapulnak, így nem tisztán geometriai jellegűek, és bizonyos típusú égi objektumokra vagy azok csoportjaira alkalmazhatók. E módszerekkel viszont sikerült a távolságmeghatározás kiterjesztése az extragalaxisok világába is. A csillagászok eddig már száznál több módszert ötlöttek ki a kozmikus távolságok megállapítására, ezzel a Világegyetem feltérképezésére, ám azzal is tisztában kell lenni, hogy e módszerek jó része kevéssé megbízható eredményt szolgáltat a távolságra - csakúgy, mint a hagyományos parallaxismeghatározás.

\section{ASZTROMETRIA AZ ÚRBŐL}

A parallaxismérés pontosságának fokozására létezik ugyan triviális megoldás, de a megvalósítás egészen a legutóbbi évtizedekig technikai nehézségekbe ütközött. A parallaktikus elmozdulás mértéke akkor mérhető pontosan, ha a vizsgált csillag koordinátáit az égbolton egészen más irányban látszó referenciacsillagokéihoz viszonyítjuk. Földi távcsövek használatával ez lehetetlen, egyrészt a távcsövek kis látómezeje miatt, másrészt a földi légkörben fellépő fénytörés (refrakció) hely- és időfüggésének bizonytalan ismerete következtében. A megoldás ezért az, hogy a pozícióméréseket a földi légkörön kívül kell végezni, és nem hagyományos távcsővel, hanem olyan optikai elrendezést megvalósítva, amellyel egymástól egészen eltérő irányban levő égi fényforrások helyzetének mérése is lehetséges (1. ábra). Ez az igény vezetett az ürasztrometria kialakulásához. 

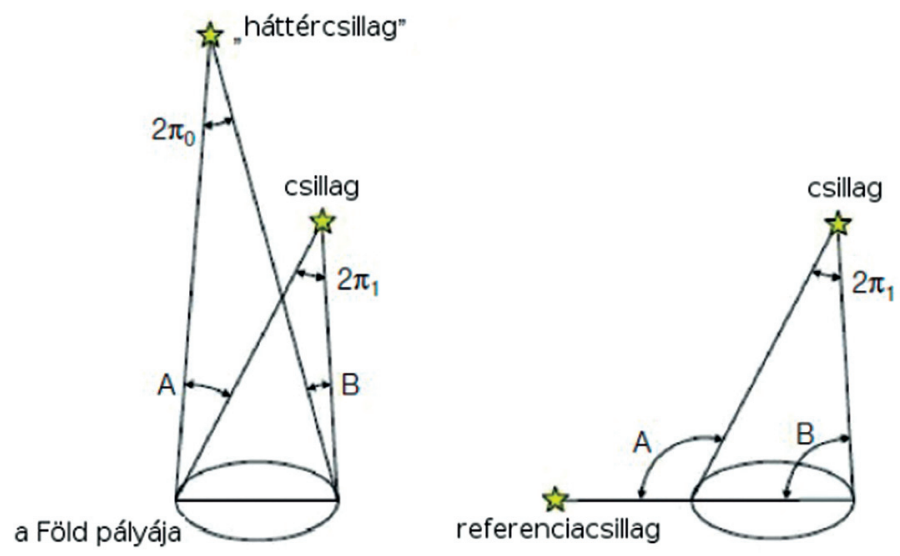

1. ábra. A parallaxis mérésének elve. Balra a relatív parallaxis, jobbra az abszolút parallaxis meghatározásának sematikus ábrázolása látható (URL1)

Az ürcsillagászati projektek elképesztően magas költsége miatt kiélezett verseny folyik a különféle csillagászati témák művelői között a tekintetben, hogy milyen méréseket végző ürszondák megvalósítását hagyják jóvá. A kozmológia, a bolygókutatás és más népszerủ és sokak által müvelt témák mellett az asztrometriával foglalkozók száma alacsony, a kis létszámú társaság érdekérvényesítő képessége pedig csekély. Így egy asztrometriai célú ürszonda szükségességének elfogadtatásához az is kellett, hogy a más témákban érdekeltek közül néhányan „átszavazva” inkább egy asztrometriai szonda kifejlesztését támogassák, lemondva saját kutatási területük prioritásáról.

Pontosan ez történt az Európai Ürügynökség (ESA) illetékes tudományos bizottságában, amikor az 1980-as évek elején felvették az ESA programjába a legelső asztrometriai célú mesterséges holdat, a Hipparcost, amelynek sikeres müködése és eredményessége látványosan érzékeltette az ürasztrometriában rejlö lehetőségeket, egyben felkeltette az égi pozíciómérés pontosságának fokozása iránti igényt is. Ezek együttesen vezettek el az újabb asztrometriai ürszonda, az ugyancsak európai Gaia megvalósításához - a Hipparcos után negyed századdal.

\section{A HIPPARCOS}

Az ürasztrometriában úttörő Hipparcos 1989 és 1993 között végezte méréseit Föld körüli pályán keringve. Neve az ókori csillagászat kiemelkedő alakja, az i. e. 2. században élt görög Hipparkhosz nevére emlékeztet, de a szonda elnevezése valójában a $\boldsymbol{H i g h} \boldsymbol{P}$ recision $\boldsymbol{P a r a l l a x} \boldsymbol{C o l l e c t i n g} \boldsymbol{S}$ atellite (nagy pontosságú parallaxisgyüjtő hold) megfelelő betűiből képzett betüszó. 
Az abszolút parallaxis meghatározásának elősegítésére az éggömb két jelentősen eltérő irányában látszó csillagokat észlelték egyidejüleg a mindössze 29 cm tükörátmérőjü távcsővel. A két látóirány 58 fokos szöget zárt be egymással. Tekintettel arra, hogy minden égitest mozog a térben, meg kell oldani a térbeli mozgás okozta koordinátaváltozás elválasztását a parallaktikus eredetű látszó elmozdulás hatásától. A kétféle effektus szeparálásához legalább három éven át kell rendszeresen mérni egy-egy égitest égi pozícióját (2. ábra). A Föld Nap körüli keringése során kialakuló parallaktikus elmozdulás egyéves periódussal ismétlődve rátevődik a csillag egyedi mozgásának égi vetületére, az ún. sajátmozgásra. A Hipparcos ezért három évet kissé meghaladó időszakon át végezte 118000 előre kiválasztott csillag pozíciójának mérését. Így egy-egy csillagról nagyjából száz időpontra vonatkozó mérési adat állt rendelkezésre a program befejeztével.

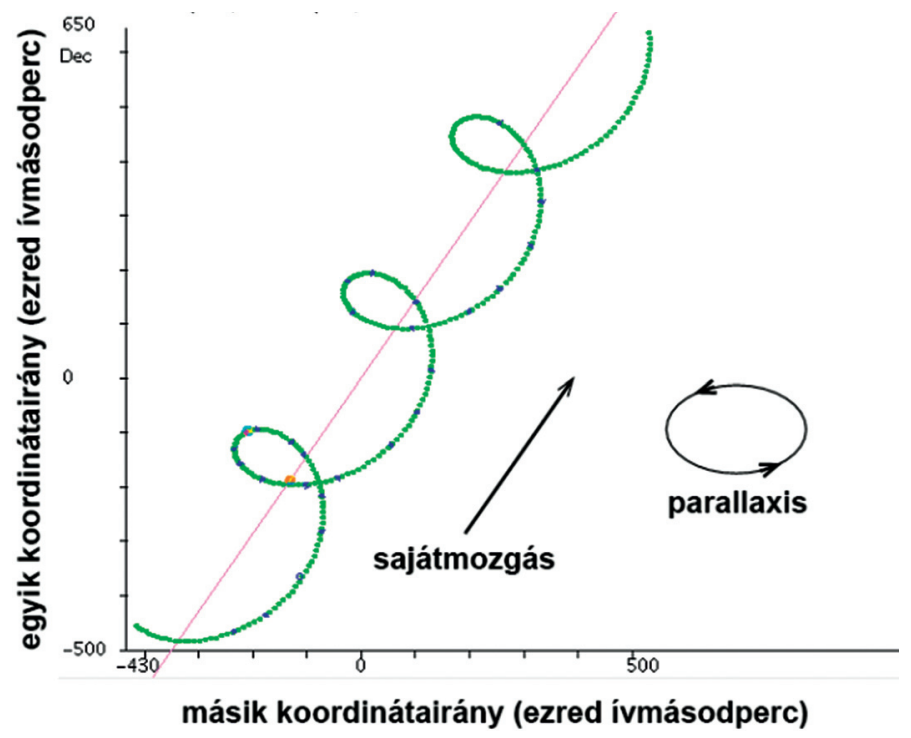

2. ábra. A parallaktikus elmozdulás és a sajátmozgás elkülönítéséhez legalább hároméves pozíciómérési sorozat szükséges (URL2; M. Richmond nyomán)

Ezek alapján két nemzetközi kutatócsoport egymástól függetlenül és egymásétól eltérő módszerrel öt asztrometriai adatot határozott meg a programban szereplö minden csillagra: az égi vonatkoztatási rendszerben érvényes két koordinátaértéket (1991,25 epochára, a mérési időszak közepére vonatkozóan), a sajátmozgás két koordinátairány menti komponensét, továbbá az égitest távolságára utaló parallaxis értékét. A programért felelős vezetők előre eldöntötték, hogy az adatfeldolgozás után kapott végeredményt csak akkor tekintik elfogadhatónak, ha azonos eredményre jut az adatredukálást végző két csoport. Mivel ez a kedvező helyzet 
következett be, 1997-ben közreadták a Hipparcos-katalógust, benne az addigi legpontosabb asztrometriai adatokkal. A közölt koordináták és a parallaxisérték pontossága 0,001 ívmásodperc, a sajátmozgásoké pedig 0,001 ívmásodperc/év.

A pozíciómérés során nemcsak annak időpontját rögzítették, hanem a vizsgált égitest pillanatnyi fényességét is, így a Hipparcos-katalógus értékes fotometriai adatbázisként is szolgál. Kifejezetten fotometriai célú ürszondák azonban csak a 21. század első évtizedétől segítik a csillagászatot (lásd Pál András tanulmányát e lapszám 889. oldalán).

A parallaxisból kapott távolság alapján az egyes csillagok luminozitása (fényteljesítménye) is pontosan meghatározható, de csak a közeli csillagokra, mert néhány ezer fényéves távolság esetén a parallaxis bizonytalansága már azonos nagyságrendủ magának a parallaxisnak a számértékével. A luminozitás ismerete viszont fontos a csillagok szerkezetének és fejlődésének megértése miatt is. A cél tehát az, hogy minél távolabbi csillagok parallaxisa is pontosan ismert legyen. A Hipparcos megmutatta, hogy az ürasztrometria jó úton jár, de a pontosság nagymértékü fokozása szükséges.

A Hipparcos eredményei közül néhányat itt is érdemes megemlíteni. A programcsillagok helyzete és mozgása alapján kimutatták, hogy a Tejútrendszer küllős spirálgalaxis. Ez azt jelenti, hogy galaxisunk centruma közelében nem egyenletesen oszlanak el a csillagok, a centrumot átszelő „küllő” két végpontjából indulnak ki a spirálkarok. A Tejútrendszer peremvidékén is talált újdonságot a Hipparcos. Kiderült, hogy galaxisunk fösíkja valójában nem sík, hanem egyik szélén lehajlik, az azzal ellentétes oldalon pedig felfelé konyul, mint egy kalap karimája. A csillagok ilyen furcsa eloszlása a Tejútrendszer tőszomszédságában található törpegalaxisok létével, illetve gravitációs hatásukkal magyarázható.

Az ürszonda fotometriai mérései alapján pedig nyilvánvalóvá vált, hogy a csillagok közül minden tizediknek időben változik a fényessége, és egy bizonyos hömérsékletértéknél hidegebb felszínü csillagok mindegyike ilyen, ún. változócsillag.

Régóta ismert, hogy a csillagok között többségben vannak azok, amelyek nem magánosak, hanem két vagy több csillagból álló rendszer tagjai. A csillagok ez esetben a rendszer tömegközéppontja körül keringenek. A Hipparcos a programcsillagok 10\%-át vizuális kettősnek észlelte, azaz komponenseire tudta bontani a kettős rendszert. A pozíciómérésekből ráadásul 235 kettőscsillag tagjainak keringési pályáját is meg tudták határozni.

\section{A GAIA - NAPJAINK LEGFONTOSABB ÜRCSILLAGÁSZATI PROJEKTJE}

A Gaia előkészítése már akkor megkezdődött, amikor a Hipparcos még javában mért, de az új asztrometriai projekt jóváhagyása és megvalósítása hosszú időt vett igénybe, így a Gaia nagyjából negyedszázaddal a Hipparcos után kezdett 
mérni. A kivitelezés során fellépett nehézségeket csupán egyetlen példával érzékeltetem. A Gaia projekt tervének körvonalazódásakor még GAIA volt a neve, a Global Astrometric Interferometer for Astrophysics kezdőbetüiből alkotott betüszóként. Csakhogy a szakemberek hosszas próbálkozások után belátták, hogy a kívánt milliomod ívmásodperces mérési pontosságot a jelenlegi technikával nem tudják az interferometria ürbeli alkalmazásával elérni, ezért a Hipparcosnál már jól bevált mérési módszernél maradtak: a csillagok átvonulási időpontját és helyét rögzítik egy nagy méretü (1 gigapixeles) CCD-érzékelöre érkező jel alapján. Mivel a betủszó így aktualitását vesztette, a GAIA névből Gaia lett.

A Gaia sok tekintetben túlszárnyalja elődjét, a Hipparcost:

- Mérési programján 118000 csillag helyett 1,6 milliárd égi forrás szerepel, és a Tejútrendszer csillagainak nagyjából egy százaléka mellett több tízezer kisbolygót és félmillió kvazárt is észlel.

- A mérési pontosság a Hipparcos ezred ívmásodperces értékéhez képest nagyjából két nagyságrendet javult, sőt a fényesebb csillagokra a néhány milliomod ívmásodperces pontosság is elérhető. İgy akár a Tejútrendszeren kívüli, közeli extragalaxisok legfényesebb csillagainak távolságát is meg lehet határozni a trigonometrikus parallaxisuk alapján.

- A mért objektumok térbeli mozgását illetően a Hipparcos-adatokból csak a sajátmozgás két komponensét (az éggömb érintősíkjában látszó mozgást) lehetett meghatározni, míg a Gaia fedélzetén levő spektrográffal legalább 15 magnitúdóig a vizsgált égitestek látóirányú (az éggömb érintősíkjára merőleges) sebessége is meghatározható a színképvonalak Doppler-eltolódása alapján. Ez lehetővé teszi a Tejútrendszer dinamikai térképének megalkotását is: a háromdimenziós térkép mellett a vizsgált csillagok térbeli mozgása is feltérképezhető, abból pedig következtetni lehet galaxisunk múltjára és jövőjére.

A 2013 végén indított Gaia 2019 nyarán már befejezte az eredetileg öt évre tervezett mérési programját, de az ESA támogatásával tovább folynak a mérések. Az elképesztő mennyiségü adat feldolgozása javában zajlik. A Gaia első adatkibocsátása (Gaia DR1) 2016 szeptemberében még csak az első 14 hónapban végzett méréseken alapult, de az ekkor közölt asztrometriai adatok már pontosabbak voltak a végső Hipparcos-katalógusban szereplőknél. A második adatkibocsátás (Gaia DR2) pedig korszakos jelentőségủ a csillagászatban, a 2018. április óta elérhető adatbázis ugyanis egyebek között a következöket tartalmazza:

- 1,7 milliárd csillag égi pozíciója és fényessége,

- 1,3 milliárd csillag parallaxisa és sajátmozgása,

- 7 millió csillag átlagos látóirányú sebessége,

- 161 millió csillag felszíni hőmérsékletének értéke,

- 77 millió csillag mérete és fényteljesítménye. 
Mivel ezeket az adatokat a mérési időszak első 22 hónapja során végzett mérésekből kapták, egyedi csillagokra még nem feltétlenül megbízhatóak az értékek. Csillagok csoportjait vizsgálva viszont már szinte azonnal rengeteg jelentős eredmény született: új csillaghalmazokat találtak galaxisunkban, sikerült kimutatni a Tejútrendszert kísérő törpegalaxisok sajátmozgását, sőt a Nagy-Magellán-felhő forgását is, a korábbiaknál pontosabban meghatározták a tejútrendszerbeli fényelnyelés mértékét, a csillagok szisztematikus mozgásából pedig becslést végeztek a galaxisunk össztömegére (beleértve a sötét anyagot is), ami 1,5 billió naptömegnek adódott, messze felülmúlva a korábban becsült értéket. Arra is fény derült, hogy a Tejútrendszer kb. 10 milliárd éve egy egész törpegalaxist kebelezett be.

A Gaia DR2 tartalmát részletező 2018-as folyóiratcikk azóta az egyik legtöbbször idézett tanulmány az egész csillagászatban. Szerzői között a Csillagászati és Földtudományi Kutatóközpont Konkoly Thege Miklós Csillagászati Intézet Gaia Adatfeldolgozó és -elemző Konzorciuma (DPAC) munkájában hosszabb-rövidebb ideje részt vevő kutatói is szerepelnek.

A következő adatkibocsátások során pedig egyre pontosabb és részletesebb adatok kerülnek nyilvánosságra, tovább fokozva a Gaia szerepét napjaink csillagászati forradalmában.

\section{IRODALOM}

URL1: https://mta.hu/tudomany_hirei/mar-elerheto-a-tejutrendszer-keszulo-haromdimenziosterkepe-106850

URL2: https://mta.hu/tudomany_hirei/itt-a-valaha-volt-legnagyobb-csillagadatbazis-nyilvanosa-gaia-urtavcso-masodik-adatkozlese-108663 